\title{
CLIMATE CHANGE IMPACTS ON COWPEA PRODUCTIVITY IN NIGERIA
}

Ajetomobi $\mathrm{J}^{* 1}$ and A Abiodun ${ }^{2}$

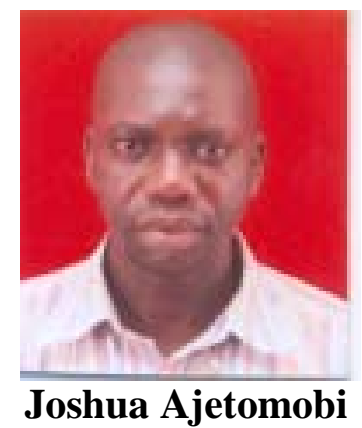

*Corresponding author Email : jsegun2002@yahoo.com

${ }^{1}$ Reader, Department of Agricultural Economics and Extension, Ladoke Akintola University of Technology, PMB 4000, Ogbomoso, Nigeria.

${ }^{2} \mathrm{PhD}$ student, Department of Agricultural Economics and Extension, Ladoke Akintola University of Technology, PMB 4000, Ogbomoso, Nigeria. 


\section{ABSTRACT}

If a climate signal could be detected at state or regional level, it would be useful to policy planners, agricultural authority and farmers to prepare for climate change. This study, therefore, employed a statistical model to investigate the relationship between the yield of cowpea and temperature (in centigrade) and precipitation (in millimeters) for the period $1961-2006$ at state levels in Nigeria. The analyses were based on all the twenty major cowpea producing states for the main period $1961-2006$. Data for annual yield of cowpea for all the time period were collected from the Nigeria Bureau of Statistics (N.B.S). Data on the two important climate variables required for crop growth - temperature and precipitation - at state in Nigeria were obtained from the Nigerian Metrological Agency. The response of cowpea yield to climate change varied from one geographical location to the other. The results indicated negative and significant relationship between cowpea yield and temperature in six of the twenty states producing cowpea in the country. Five of the six states are in the northern part while the remaining one is in the south. The results of the relationship between the yield and precipitation were similar to those of temperature in the northern states, except Sokoto. There was a negative correlation between rainfall and cowpea yield in Adamawa, Bauchi, Kaduna, Katsina, Kwara, Niger Plateau and Yobe. On the contrary, increase in precipitation will lead to increase in yield in the southern part except Kwara. The time trend is positive and significant in all the cases except in Adamawa, Bauchi and Jigawa where time trend was non significant though positive..These results also show that as the years pass by and climate factors run contrary to agricultural productivities, cowpea farmers were adopting new measures to cope with the negative effect of climate change. Through adaptation, the negative effects of climate change on cowpea yield could be reduced and the positive influences enhanced. Examples of potential adaptive measures include the introduction of drought or heat resistant varieties, early sowing, mixed cropping, alteration of the tillage system and utilization of land that has been considered too marginal for agricultural cultivation.

Key words: Climate change, statistical modeling, Nigeria 


\section{INTRODUCTION}

Climate change through extreme temperature, frequent flooding and drought and increased salinity of water used for irrigation has become a recurrent subject of debate globally including Nigeria. When the United Nations Framework Convention on Climate Change (UNFCCC) was opened for signatures in June 1992, Nigeria was among 154 countries that signed the convention which entered into force on 21 March 1994. Nigeria ratified the Convention in August 1994. Like other developing countries, the challenge of climate change and global warming is enormous in Nigeria due to widespread poverty, prevailing slash-and-burn agriculture, erosion and burning of firewood and farm residues. Though climate change is a threat to agricultural and non-agricultural socioeconomic development, agricultural production activities are generally more vulnerable to climate change than other sectors. Quite substantial work has been done in this respect at national, regional and global aggregate level using various approaches such as divide and conquer, Ricardian, and statistical model $[1,2,3,4]$. The aim of the approaches is to create better understanding of how agricultural practices can be sustainable [3]. In Canadian agriculture, there exists a statistical significance of climate variables along with latitude and population density, although no degree of precision can accurately be ascertained [5]. In the USA, it has been discovered that if land is irrigated, then, a valuable buffer will be provided against adverse climatic conditions [6]. In Sri Lanka when precipitation increases, it results in a positive and significant impact on farmers' revenues, whereas temperature has a strong negative impact. The level of education of the household head and land tenure status were other important variables [7]. In Norway, there is a positive impact on crop yields from increased temperature [3]. The effect is strongest for potatoes. In Cameroon, net revenue falls as precipitation decreases or as temperature increases [8]. In Egypt, high temperatures will constrain agricultural production [9]. In South Africa, climate change has significant non-linear effects on net revenue per hectare of sugarcane with higher sensitivity to future increase in temperature than precipitation [2].

In spite of all the existing evidence that developing countries' agriculture is more likely to be negatively affected by climate change, more efforts have been made to quantify the impact in developed countries [10]. Even then, there has been little research carried out in Nigeria. The vulnerability of the Nigerian agricultural sector to climate change is of particular interest to policy makers because agriculture is a key sector in the economy accounting for between $60-70 \%$ of the labour force and contributing between $30-40 \%$ of the nations GDP [11]. The sector is also the source of raw materials used in the processing industries as well as a source of foreign exchange earnings for the country. How much one can hold climate responsible for changes in agricultural productivity in Nigeria will, for a long time, remain a subject of research as long as other factors are at interplay in determining agricultural productivity. The production of major export crops in the country such as groundnut, rubber, coffee, cocoa and palm have declined in magnitude since the drought of $1972 / 73$, which is the first real evidence of climate change in Nigeria. Though there is evidence of increase in food crop production generally in Nigeria, the nation is not

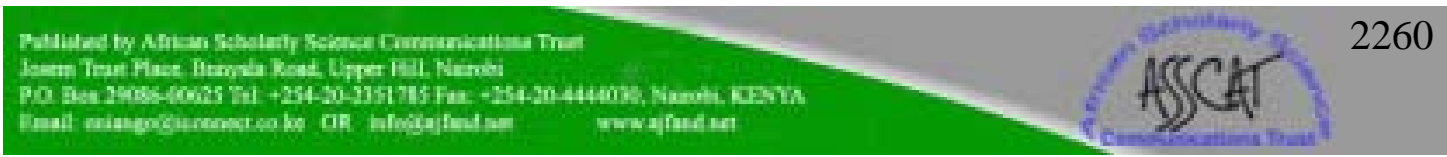


self sufficient in production of any food crop except cassava. The question remains, therefore, as to whether the production level will ever meet the demand level given the rate of population growth in the country. By and large, the impact of climate change on production and adaptation options in Nigeria is an important research focus at present.

A recent research has shown that grains can be used to offset the major impacts of climate change because of their unique position as staple for the growing populations. This accounts for the interest of this work on cowpea. In Nigeria as well as in other West and Central African countries, cowpea is of major importance to the livelihoods of millions of people providing nourishment and an opportunity to generate income. Trading fresh produce and processed food and snacks provides rural and urban women with the opportunity for earning cash income; and as a major source of protein, minerals, and vitamins in daily diets, it positively impacts on the health of women and children. At present, Nigeria is the largest producer and consumer of cowpea worldwide with about 5 million ha and over 2 million t production annually. Every Nigerian eats cowpea and the per capita consumption is about 25 to $30 \mathrm{~kg}$ per annum [12].

Despite the importance of cowpea, its production like other grains is beset with constraints such as drought, flooding, salt stress and extreme temperatures, all of which are expected to worsen with climate change. Drastic changes in rainfall patterns and rise in temperatures will introduce unfavourable growing conditions into the cropping calendars thereby modifying growing seasons which could subsequently reduce crop productivity. In order to formulate appropriate adaptive strategies and policies, the underlying processes and short and long run directions of such changes need to be well understood. The main objective of this study, therefore, was to analyze the effect of climate change on cowpea yield in Nigeria.

\section{Climate variability and climate change in Nigeria and its effects on cowpea}

Climate change impacts usually depend on a range of the climate parameters' changes and on the country's social, cultural, geographical and economic backgrounds. In Nigeria, the location and size of, and the characteristics of the relief give rise to various types of climates ranging from tropical rainforest along the coasts to sahel climate in the northern parts of the country. The climate of the country strides from a fairly wet coastal area with annual rainfall greater than $3500 \mathrm{~m}$ to the sahel region in the northwestern and northeastern parts with annual rainfall of less than $600 \mathrm{~mm}$ [11]. The inter-annual variability of rainfall, particularly in the northern parts is large, often results in climate hazards, especially floods and droughts with their devastating effects on food production and associated calamities and human sufferings. More often than not, certain parts of Nigeria receive less than 75 percent of their annual rainfall and this is particularly worrisome in the north. By virtue of Nigeria's location primarily within the lowland humid tropics, the country is generally characterized by a high temperature regime almost through the year. In the far south, mean maximum temperature is between $30^{\circ} \mathrm{C}$ and $32^{\circ} \mathrm{C}$ while in the north it is between $36^{\circ} \mathrm{C}$ and

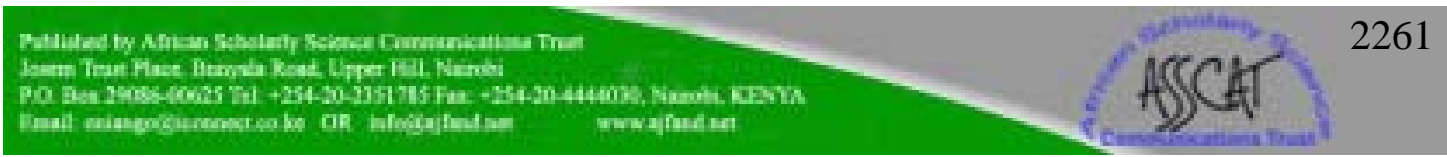


$38^{\circ} \mathrm{C}$. However, the mean minimum temperature is between $20^{\circ} \mathrm{C}$ and $22^{\circ} \mathrm{C}$ in the south and under $13^{\circ} \mathrm{C}$ in the north which has a much higher annual range. The mean temperature for the country is between $27^{\circ} \mathrm{C}$ and $29^{\circ} \mathrm{C}$.

In the absence of altitudinal modifications, the diverse nature of the country's climate consequently gives rise to a high degree of biological diversity resulting mainly in six vegetation zones: the mangrove swamps, the saltwater and freshwater swamps, tropical lowland rainforests, guinea savanna, sudan savanna, and sahel savanna. Salt and fresh water swamps are along the coast of Nigeria. The salt-water swamps stretch inland for 1-2 km in the Lagos area to over $30 \mathrm{~km}$ in the Sapele area. Further inland, beyond the reach of tidal waters, mangroves give way to freshwater plants, the most important of which is the raffia palm. From a water balance perspective, the country experiences large spatial and temporal variations in rainfall, and less variation in evaporation and evapo-transpiration. Consequently, rainfall is by far the most important element of climate in Nigeria and thereby becomes a critical index for assessing agricultural and water resources potential in the country.

Based on the Intergovernmental Panel on Climate Change (IPCC) projection, the humid tropical zone of southern Nigeria, which is already too hot and too wet is expected to be characterized by increase in both precipitation (especially at the peak of the rainy season) and temperature. Already, temperature increases of about $0.2^{\circ} \mathrm{C}$ $0.3^{\circ} \mathrm{C}$ per decade have been observed in the various ecological zones of the country, while drought persistence has characterized the sudan-sahel regions, particularly since the late 1960s. For the tropic humid zones of Nigeria, precipitation increases of about $2-3 \%$ for each degree of global warming may be expected. Thus, it is reasonable to expect that the precipitation would probably increase by approximately $5-20 \%$ in the very humid areas of the forest regions and southern savanna areas. The increase in temperature in these areas would also possibly increase evaporation, reducing the effectiveness of the increase in precipitation. According to IPCC projections, rainfall in the very humid regions of southern Nigeria is expected to increase. This may be accompanied by increase in cloudiness and rainfall intensity, particularly during severe storms. It could also result in shifts in geographical patterns of precipitation and changes in the sustainability of the environment and management of resources. However, since the increase in temperature could increase evaporation and potential evapo-transpiration, there would be tendency towards "droughts" in parts of these humid areas of the country. In fact, recent studies have shown that precipitation decrease in the humid regions of West Africa, including southern Nigeria, since the beginning of the century is about $10-25 \%$ or about $2-5 \%$ per decade. If this trend persists, rainfall in the humid regions of southern Nigeria may be about $50 \%$ to $80 \%$ of the 1900 values by 2100 . With increase in ocean temperatures, however, there could be increase in the frequency of storms in the coastal zone of the country. In contrast to the humid areas of southern Nigeria, the savanna areas of northern Nigeria would probably have less rainfall, which, coupled with the temperature increases, would reduce soil moisture availability. Recent studies have indicated that the sudansahel zone of Nigeria has suffered a decrease in rainfall in the range of about 30-40\% or about $3 \%-4 \%$ per decade since the beginning of the nineteenth century. Already, 
these savanna and semi-arid areas suffer from seasonal and inter annual climatic variabilities, and there have been droughts and effective desertification processes, particularly, since the 1960s. This situation may be worsened by the expected decrease in rainfall with greater drought probabilities and more rainfall variabilities and unreliabilities. Part of the conclusions of IPCC's third assessment report is that during the $21^{\text {st }}$ Century, some extreme climatic events will increase in frequency and/or severity due to changes in the mean and/or variability of climate. Some of these events will have negative impacts on agricultural production.

In terms of implication on Nigerian agriculture, cereals (notably millet and sorghum), groundnuts and cowpea dominate crop production in the northern part of the country, while the dominant crops in the south are cassava, yam, palm produce, cocoa and rubber. It is a significant sector of the economy and also the source of a lot of raw materials used in the processing industries, as well as a source of foreign exchange earning for the country. It follows, therefore, that any change in climate is bound to impact on the agricultural sector in particular and other socio-economic activities in general. Climate change could have both positive and negative impacts. The impacts could be measured in terms of effects on crop growth, availability of soil water, soil fertility, soil erosion, incidents of pests and diseases, and sea level rise, which also influence the yield of crops amidst other factors such as fertilizer, cultural practices, and managerial abilities of the farmers.

In respect of cowpea, it can be planted in soils that vary from sandy to clayey, but soil that is easily waterlogged must be avoided. Nitrogen fixation, which is a characteristic of legumes, is inhibited in waterlogged soils. Production is also possible on marginal soils. On less fertile soils cowpeas can produce some protein-rich vegetative material as well as seed. Neutral soil $\mathrm{pH}$ is optimal for cowpea production. However, cowpeas can also be planted in acid soils where aluminium toxicity occurs. Cowpeas can be produced successfully in areas where soil fertility and $\mathrm{pH}$ are not suitable for the production of maize. For optimal production, soils must have a depth of at least $1 \mathrm{~m}$ to ensure sufficient root development to maintain the plant during drought. Cultivation can begin early in the season as soon as the minimum temperature remains above $10^{\circ} \mathrm{C}$. The best vegetative growth is possible with temperatures varying from 21 to $33^{\circ} \mathrm{C}$, while higher temperatures can cause earlier flowering and flower abscission, resulting in poor pod set.

\section{Description of the model}

The study employed statistical model that relates yield per hectare to meteorological data [4]. The study assumed a quadratic relationship between yield per hectare, Y and temperature, $\mathrm{T}$, precipitation, $\mathrm{P}$, and a time trend, $\tau$. Annual mean temperature was measured in degree centigrade while precipitation was measured in millimeters. The equation is

$Y_{i t}=a_{i}+b_{j} T_{j t}+c_{j} P_{j t}+d_{j} T_{j t}^{2}+e_{j} P_{j t}^{2}+\theta \tau+w_{j t}$ 
Where $\mathrm{j}$ is the state index, $\mathrm{t}$ is the time index, denoting annual observations from 1961 to $2006 . \mathrm{w}_{\mathrm{jt}}$ is the error term. The estimated parameters are a,b,c,d,e and $\theta$.

A time trend has been included in the model. This served as a proxy, for the noninclusion of some non climate variables which are important in agricultural productivity. Such factors include technological change and innovations (improvement in agricultural inputs/and or practices and/or changes in production patterns), increased productivity due to other climate variables and a fertilizer effect from increased $\mathrm{CO}_{2}$ concentration in the atmosphere. Although sunlight is another important weather variable necessary for crop growth it was not possible to include it in the analysis because the meteorological stations did not have the data or its proxy for the period of the study.

\section{Data Description and Sources}

The dependent variable is yield per hectare while the explanatory variables are weather data, namely, annual mean temperature, measured in centigrade, the annual precipitation measured in millimeters and a time trend. The analyses were based on all the twenty major cowpea producing states for the main period 1961 -2006. Data for annual yield of cowpea for all the time period were collected from the Nigeria Bureau of Statistics (N.B.S). The annual yield of cowpeas was calculated by dividing the total production of each crop per state by the total agricultural area employed in the cultivation of cowpeas in that state, and was measured in kilograms per hectare. There are some cases where values of cowpea production and area were missing for some of the states. In such cases, interpolations were made by finding the average of the preceding values and the one following, and the missing values were represented by the average.

Two important climate variables required for crop growth had been employed in this study .These are temperature and precipitation at state or regional level in Nigeria. The data were obtained from the Nigerian Metrological Agency as reported in the annual abstract of the Central Bank of Nigeria Statistical Bulletin, covering a forty five- year period from 1961 to 2006. Annual precipitation is measured in millimeters. The second weather variable is temperature measured in centigrade. The precipitation used in the analysis is the annual precipitation rather than monthly precipitation for only the cropping months. This is because a significant part of the publication falling outside the cropping months will be retained inside the soil as moisture content and hence contributing to crop growth at the onset of the cropping seasons.

\section{RESULTS}

The descriptive statistics of the data used in the estimation of the statistical model are presented in Figures 1 to 3. Over the entire analysis period (1961-2006) average cowpea yield varied from 0.10 to 1.55 tonnes per hectare (Figure 1). The highest cowpea yield was recorded in Benue state followed by Kaduna and Kwara state, respectively. Other major producers include Anambra state (0.98 tonnes per hectare), 


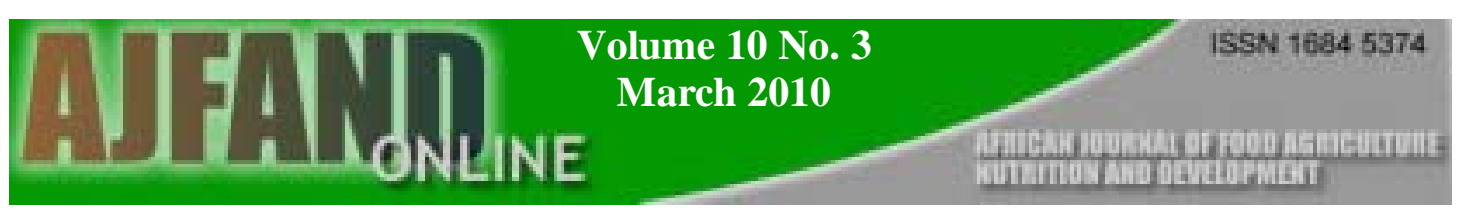

Yobe state $(0.90$ tonnes per hectare), and Oyo state ( 0.83 tonnes per hectare). The lowest average yield is found in Kano State. Other states producing less than 0.5 tonnes per hectare include Jigawa, Zamfara, Niger, Borno, Katsina, Plateau and Sokoto states.

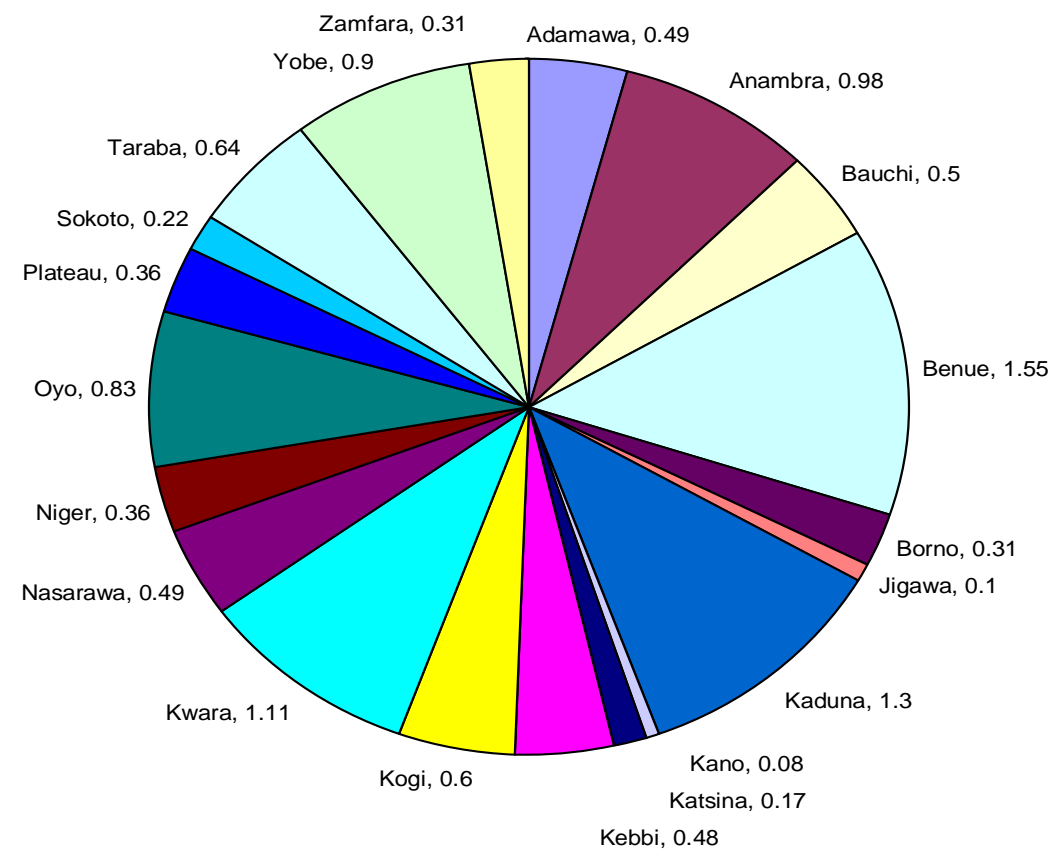

\section{Figure 1: Cowpea Yield in tonnes/hectare in Nigeria}

Figure 2 shows that the highest average annual rainfall $(1711 \mathrm{~mm})$ is recorded in Anambra state in the southern part of the nation followed by Oyo State (1468.41mm). Other cowpea producing states with relatively high rate of precipitation are Nasarawa, Kaduna, Kwara and Niger states. Zamfara state in the north has the lowest average annual rainfall $(447.65 \mathrm{~mm})$. Borno, Jigawa, Kebbi and Sokoto states equally have relatively low level of average annual precipitation. 

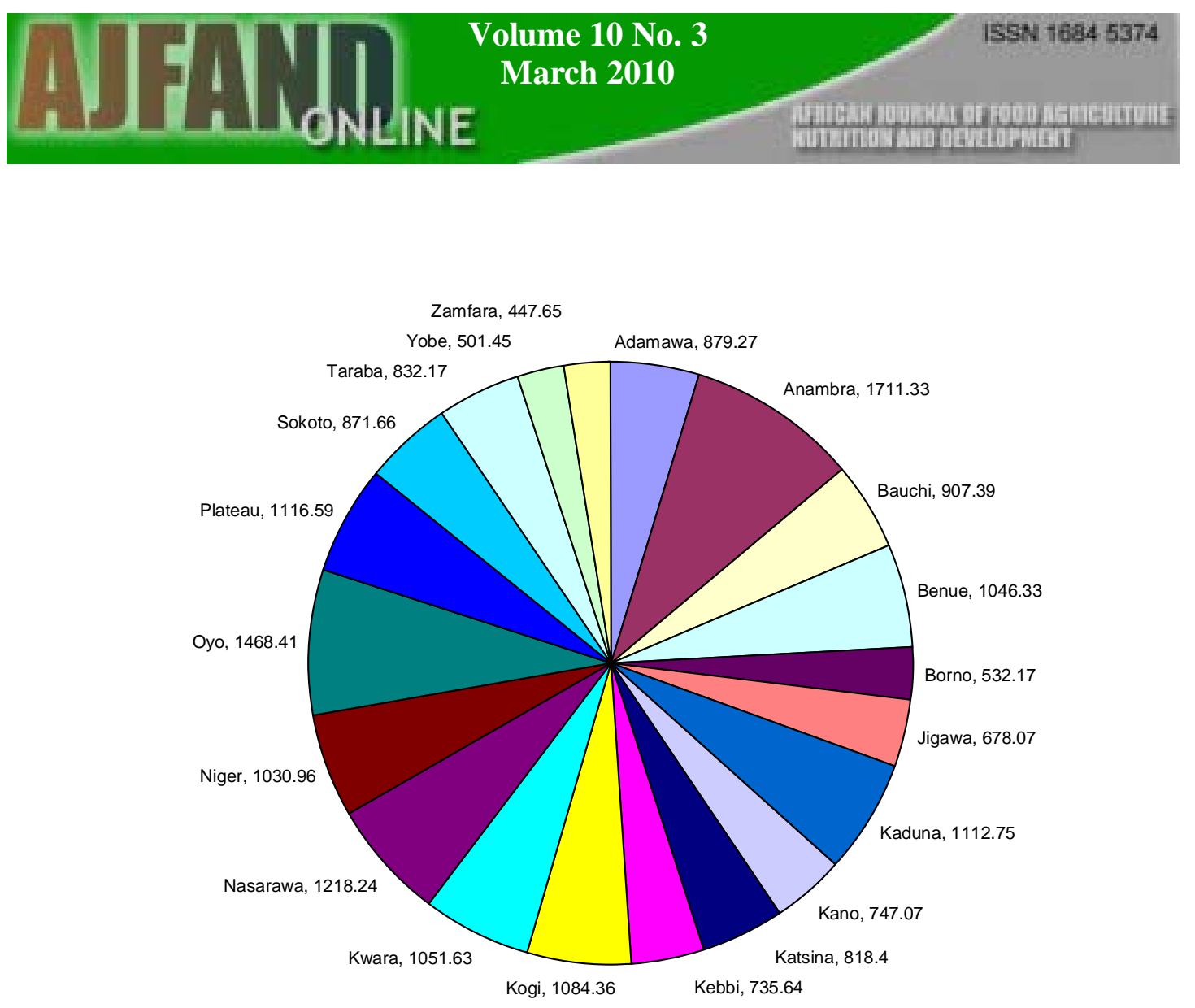

Figure 2: Rainfall (in millimeters) pattern of Cowpea Producing States in Nigeria

The hottest cowpea producing state is Sokoto with average temperature of $34.30^{\circ} \mathrm{C}$ followed by Kebbi state (figure 3). Other cowpea producing states with greater than $30^{\circ} \mathrm{C}$ average annual temperature include Bauchi, Benue, Yobe and Kaduna. They are all in the northern part of the country. The coldest is Plateau state with the average annual temperature of $24.2^{\circ} \mathrm{C}$. 


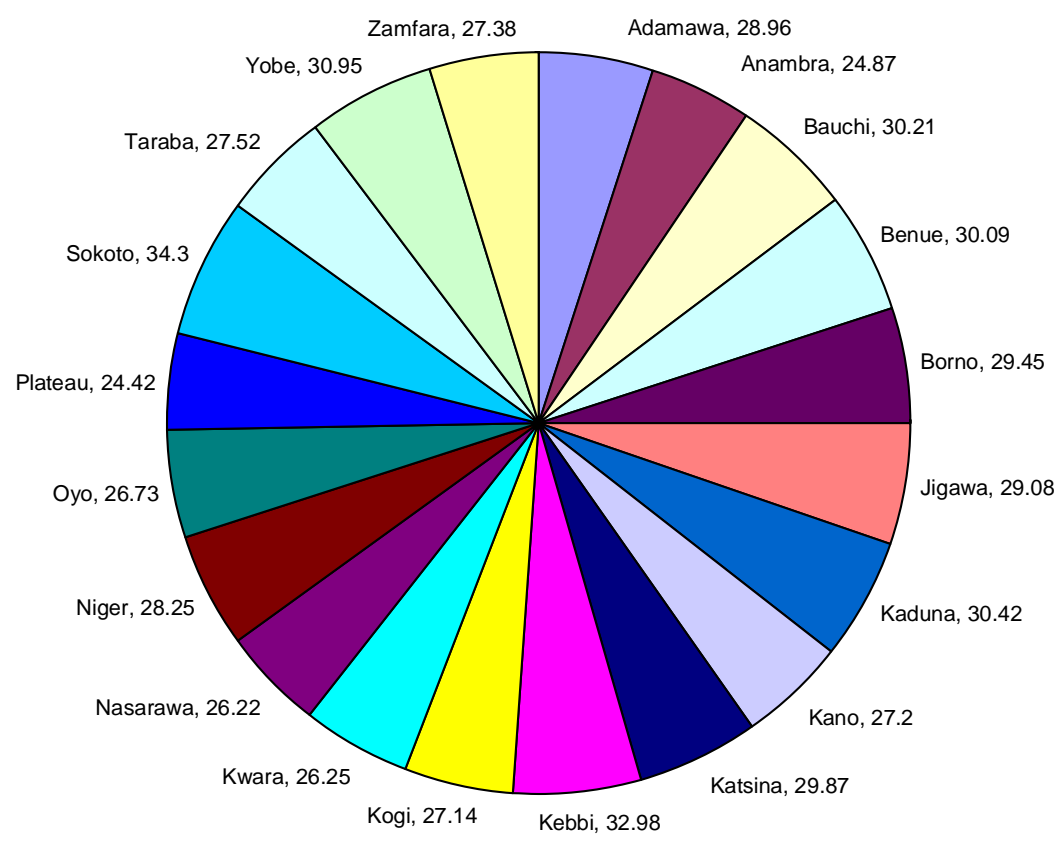

\section{Figure 3: Temperature (in degrees centigrade) Pattern of Cowpea Producing States in Nigeria}

The regression results are presented in Table 1. The Table shows that temperature is significant at 5\% level in some of the northern states. Out of the thirteen northern states included in the analysis, five of them, Adamawa, Jigawa Kaduna, Sokoto and Yobe have a significant response of cowpea yield to an increased temperature. Out of these five northern states, only two of them, Adamawa and Jigawa have a positive relationship between cowpea yield and increased temperature. The remaining three have negative relationship. Kogi is the only state situated in central Nigeria that has a positive and significant relationship between cowpea yield and temperature. As temperature increased by one degree centigrade, the yield of cowpea increased by a factor of 2.942. Kwara and Oyo are situated in the southern part of Nigeria while the only cowpea producing state in the east is Anambra. The regression result for Kwara and Oyo are different. Temperature is positively correlated with cowpea yield in Kwara while the reverse is the case in Oyo. This might be connected with the availability of the lower Niger River Basin Development Authority present in Kwara farms. In Anambra, a rise in temperature by one centigrade would lead to a 0.54 increase in cowpea yield (Table 1).

The second weather variable is precipitation. The regression result shows that precipitation is most likely to be a major limiting weather factor in the production of cowpea in the northern states. There is a negative and significant relationship between 
rainfall and cowpea yield in Adamawa, Bauchi, Kaduna, Katsina, Kwara, Niger Plateau and Yobe. The geographical location and the harsh climate condition of these regions adduce to the result. All other remaining states have positive relationship between precipitation and cowpea yield (Table 1). The time trend is positive and significant in all the cases except in Adamawa, Bauchi and Jigawa where time trend was insignificant though positive.

\section{DISCUSSION}

The variability in the average yield of cowpea in the various producing states is a true reflection of the soil and climatic condition required for cowpea production. The crop thrives well in a soil that varies from sandy to clayey, but soil that is easily waterlogged must be avoided. This is because Nitrogen fixation, which is a characteristic of legumes, is inhibited in waterlogged soils. For optimal production, soils must have a depth of at least $1 \mathrm{~m}$ to ensure sufficient root development to maintain the plant during drought. The cultivation can begin early in the season as soon as the minimum temperature remains above $10{ }^{\circ} \mathrm{C}$. The best vegetative growth is, however, possible with temperatures varying from 21 to $33{ }^{\circ} \mathrm{C}$, while higher temperatures can cause earlier flowering and flower abscission, resulting in poor pod set. High night temperatures (above $\pm 17{ }^{\circ} \mathrm{C}$ ) can cause flower abscission in some cultivars during flowering. Cowpea is drought tolerant and can be produced in areas where few other crops would survive. Well-distributed rainfall of $450 \mathrm{~mm}$ per year will be sufficient to produce 1 tonne seed/ha and $4 \mathrm{t}$ hay/ha. The average temperature of the state with the highest yield (Benue) is 30.09. The average rainfall is $1046.33 \mathrm{~mm}$. The temperature and rainfall are lower in Jigawa state, which has the lowest cowpea yield. Apart from favourable climatic conditions, another factor for better average yield of cowpea in the mid-western and north central part of Nigeria is the significant advances made by the International Institute of Tropical Agriculture (IITA) based in Ibadan, Nigeria, over the last two decades in improving production in the area. Several drought and pest resistant cowpea varieties are developed and adopted by cowpea farmers in the region, to mitigate against the side effects of climate variability.

Table 1 shows that the negative correlation between cowpea yield and temperature in the three northern states is expected given the extremely high temperature as a result of intense sunshine and desertification in the region. The positive response obtained for some of the northern states is probably as a result of other factors that served in cushioning the effect of the high temperature. For example, irrigation system is functioning fairly well in Jigawa, and Kebbi states. The positive influence obtained in Kogi state can be explained by the fact that rainfall pattern in Kogi state is mostly of the conventional type, so that a high temperature at any particular period of the day could be offset by a heavy downpour in the later part of the day. The use of irrigation water in the state also helps the crop to cope with heat stress that comes due to a temporary drought such as august breaks and/or intense sunshine. Another study that finds a negative impact from increased precipitation on agricultural production is

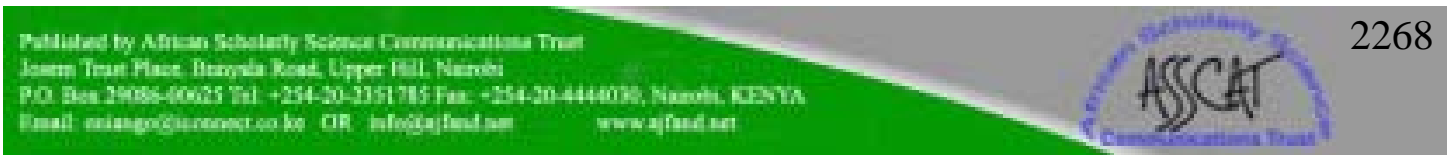


where a dynamic crop model is modified to simulate effects of heavy precipitation and excess soil moisture on corn production in the U.S corn belt) [13].

The negative coefficient of rainfall in 5 of the northern state is not surprising because the growing season for cowpea sometimes coincides with the period of heavy torrential rain usually accompanied by heavy storm. The flooding usually waterlogs, which is not a conducive environment for cowpea production.

The positive coefficient of trend variable in Adamawa, Bauchi and Jigawa shows that as the years went by and climate factors ran contrary to agricultural productivities, cowpea farmers were also adopting new measures to cope with the negative effect of climate change. For example, technological innovation is important such as the planting of early maturing seed, drought resistant varieties and the use of fertilizer, and adoption of improved farming practices. All these explain the high and positive correlation of the time trend with the yield of cowpea.

\section{CONCLUSION}

The study shows that cowpea yield is likely to respond to climate change in Nigeria. The response of cowpea yield to climate change varies from one geographical location to the other. These results also showed that as the years went by and climate factors ran contrary to agricultural productivities, cowpea farmers were also adopting new measures to cope with the negative effect of climate change. Through adaptation the negative effects of climate change on cowpea yield could be reduced and the positive influences enhanced. Examples of potential adaptive measures include the introduction of drought or heat resistant varieties, early sowing, mixed cropping, alteration of the tillage system and utilization of land that has been considered too marginal for agricultural cultivation. 
Table 1: Regression between Cowpea Yield and Climate Variables

\begin{tabular}{|c|c|c|c|c|c|c|c|}
\hline States & Constant & $\mathrm{T}$ & $\mathrm{P}$ & $\mathrm{T}^{2}$ & $\mathrm{P}^{2}$ & TREND & $\mathrm{R}^{2}$ \\
\hline Adamawa & $\begin{array}{l}-1.769 \\
(-1.104)\end{array}$ & $\begin{array}{l}0.142 \\
(1.281)\end{array}$ & $\begin{array}{l}-1.32 \times 10^{-5} \\
(-0.039)\end{array}$ & $\begin{array}{l}-0.002 \\
(-1.250)\end{array}$ & $\begin{array}{l}8.73 \times 10^{-10} \\
(0.004)\end{array}$ & $\begin{array}{l}0.010^{*} \\
(4.339)\end{array}$ & 0.37 \\
\hline Anambra & $\begin{array}{l}-6.100 \\
(-1.423)\end{array}$ & $\begin{array}{l}0.534^{* *} \\
(1.581)\end{array}$ & $\begin{array}{l}0.000 \\
(1.111)\end{array}$ & $\begin{array}{l}-0.011^{* *} \\
(-1.653)\end{array}$ & $\begin{array}{l}-1.56 \times 10^{-8} \\
(-1.061)\end{array}$ & $\begin{array}{l}0.018 \\
(0.005)\end{array}$ & 0.41 \\
\hline Bauchi & $\begin{array}{l}-3.359 \\
(-0.205)\end{array}$ & $\begin{array}{l}0.251 \\
(0.247)\end{array}$ & $\begin{array}{l}0.001 \\
(1.198)\end{array}$ & $\begin{array}{l}-0.005 \\
(-0.315)\end{array}$ & $\begin{array}{l}-4.83 \times 10^{-7} \\
(-1.281)\end{array}$ & $\begin{array}{l}0.015^{\text {*** }} \\
(1.644)\end{array}$ & 0.47 \\
\hline Benue & $\begin{array}{l}-0.452 \\
(-0.046)\end{array}$ & $\begin{array}{l}0.130 \\
(.196)\end{array}$ & $\begin{array}{l}0.002^{* *} \\
(1.589)\end{array}$ & $\begin{array}{l}-0.004 \\
(-0.322)\end{array}$ & $\begin{array}{l}-9.81 x^{-7 * *} \\
(-1.653)\end{array}$ & $\begin{array}{l}0.029^{*} \\
(4.792)\end{array}$ & 0.50 \\
\hline Borno & $\begin{array}{l}-1.397 \\
(-0.489)\end{array}$ & $\begin{array}{l}0.118 \\
(0.650)\end{array}$ & $\begin{array}{l}0.000 \\
(-0.688)\end{array}$ & $\begin{array}{l}-0.002 \\
(-0.755)\end{array}$ & $\begin{array}{l}3.46 \times 10^{-7} \\
(0.691)\end{array}$ & $\begin{array}{l}0.007^{*} \\
(3.110)\end{array}$ & 0.47 \\
\hline Jigawa & $\begin{array}{l}-8.794^{*} \\
(-2.101)\end{array}$ & $\begin{array}{l}0.629 \\
(2.116)\end{array}$ & $\begin{array}{l}3.70 \times 10^{-5} \\
(0.511)\end{array}$ & $\begin{array}{l}-0.011^{*} \\
(-2.113)\end{array}$ & $\begin{array}{l}-2.38 \times 10^{-8} \\
(-0.533)\end{array}$ & $\begin{array}{l}0.003^{* *} \\
(1.870)\end{array}$ & 0.43 \\
\hline Kaduna & $\begin{array}{l}10.165^{*} \\
(2.529)\end{array}$ & $\begin{array}{l}-0.589 \\
(-.105)\end{array}$ & $\begin{array}{l}0.000 \\
(-0.329)\end{array}$ & $\begin{array}{l}0.009^{*} \\
(2.040)\end{array}$ & $\begin{array}{l}3.40 \times 10^{-7} \\
(0.534)\end{array}$ & $\begin{array}{l}0.029^{*} \\
(5.802)\end{array}$ & 0.43 \\
\hline Kano & $\begin{array}{l}0.019 \\
(0.578)\end{array}$ & $\begin{array}{l}0.004 \\
(1.202)\end{array}$ & $\begin{array}{l}7.60 \times 10^{-6} \\
(0.092)\end{array}$ & $\begin{array}{l}0.000^{* * *} \\
(-1.673)\end{array}$ & $\begin{array}{l}-8.87 \times 10^{-9} \\
(-0.177)\end{array}$ & $\begin{array}{l}0.002^{*} \\
(6.076)\end{array}$ & 0.44 \\
\hline Katsina & $\begin{array}{l}-0.128 \\
(-0.254)\end{array}$ & $\begin{array}{l}0.026 \\
(0.788)\end{array}$ & $\begin{array}{l}-1.84 \times 10^{-4} \\
(-0.233)\end{array}$ & $\begin{array}{l}0.000 \\
(-1.159)\end{array}$ & $\begin{array}{l}-5.41 \times 10^{-9} \\
(-0.119)\end{array}$ & $\begin{array}{l}0.005^{*} \\
(3.673)\end{array}$ & 0.45 \\
\hline Kebbi & $\begin{array}{l}-13.734^{\text {** }} \\
(-1.663)\end{array}$ & $\begin{array}{l}0.849^{* *} \\
(1.647)\end{array}$ & $\begin{array}{l}0.000 \\
(0.328)\end{array}$ & $\begin{array}{l}-0.013^{* *} \\
(-1.638)\end{array}$ & $\begin{array}{l}-9.83 \times 10^{-8} \\
(-0.137)\end{array}$ & $\begin{array}{l}0.009^{*} \\
(5.097)\end{array}$ & 0.45 \\
\hline Kogi & $\begin{array}{l}-39.688^{*} \\
(-4.383)\end{array}$ & $\begin{array}{l}2.942^{*} \\
(4.428)\end{array}$ & $\begin{array}{l}0.000 \\
(1.119)\end{array}$ & $\begin{array}{l}-0.055^{*} \\
(-4.457)\end{array}$ & $\begin{array}{l}-1.34 \times 10^{-7} \\
(-0.682)\end{array}$ & $\begin{array}{l}0.019^{*} \\
(6.230)\end{array}$ & 0.60 \\
\hline Kwara & $\begin{array}{l}-1.673 \\
(-0.526)\end{array}$ & $\begin{array}{l}0.199 \\
(0.873)\end{array}$ & $\begin{array}{l}0.000 \\
(-0.602)\end{array}$ & $\begin{array}{l}-0.004 \\
(-1.036)\end{array}$ & $\begin{array}{l}3.56 \times 10^{-7} \\
(0.902)\end{array}$ & $\begin{array}{l}0.025^{*} \\
(6.308)\end{array}$ & 0.46 \\
\hline Nasarawa & $\begin{array}{l}-1.617^{* *} \\
(-1.527)\end{array}$ & $\begin{array}{l}0.129^{* * *} \\
(1.731)\end{array}$ & $\begin{array}{l}8.29 \times 10^{-5} \\
(0.085)\end{array}$ & $\begin{array}{l}-0.002^{* *} \\
(-1.588)\end{array}$ & $\begin{array}{l}-1.11 \times 10^{-8} \\
(0.025)\end{array}$ & $\begin{array}{l}0.009^{*} \\
(4.602)\end{array}$ & 0.43 \\
\hline Niger & $\begin{array}{l}0.693 \\
(0.672)\end{array}$ & $\begin{array}{l}-0.032 \\
(-.462)\end{array}$ & $\begin{array}{l}0.000 \\
(-0.173)\end{array}$ & $\begin{array}{l}0.001 \\
(0.479)\end{array}$ & $\begin{array}{l}8.04 \times 10^{-8} \\
(0.203)\end{array}$ & $\begin{array}{l}0.007^{*} \\
(4.773)\end{array}$ & 0.35 \\
\hline Оуо & $\begin{array}{l}2.871 \\
(0.794)\end{array}$ & $\begin{array}{l}-0.151 \\
(-.598)\end{array}$ & $\begin{array}{c}7.56 \times 10^{-5} \\
(0.408)\end{array}$ & $\begin{array}{l}0.002 \\
(0.474)\end{array}$ & $\begin{array}{l}-8.26 \times 10^{-8} \\
(-0.408)\end{array}$ & $\begin{array}{l}0.017^{*} \\
(5.737)\end{array}$ & 0.41 \\
\hline Plateau & $\begin{array}{l}0.869 \\
(1.077)\end{array}$ & $\begin{array}{l}-0.045 \\
(-.724)\end{array}$ & $\begin{array}{l}0.000 \\
(-0.493)\end{array}$ & $\begin{array}{l}0.001 \\
(0.670)\end{array}$ & $\begin{array}{l}7.50 \times 10^{-8} \\
(0.468)\end{array}$ & $\begin{array}{l}0.007^{*} \\
(4.326)\end{array}$ & 0.41 \\
\hline Sokoto & $\begin{array}{l}1.833^{*} \\
(3.034)\end{array}$ & $\begin{array}{l}-0.144^{*} \\
(-2.09)\end{array}$ & $\begin{array}{l}0.000^{*} \\
(2.219)\end{array}$ & $\begin{array}{l}0.003^{*} \\
(3.192)\end{array}$ & $\begin{array}{l}-1.49 \times 10^{-8 * *} \\
(-1.815)\end{array}$ & $\begin{array}{l}0.003^{*} \\
(3.306)\end{array}$ & 0.60 \\
\hline Taraba & $\begin{array}{l}-1.795^{*} \\
(-1.415)\end{array}$ & $\begin{array}{l}0.143^{* *} \\
(1.726)\end{array}$ & $\begin{array}{l}0.001 \\
(-0.765)\end{array}$ & $\begin{array}{l}-0.003^{* *} \\
(-1.854)\end{array}$ & $\begin{array}{l}-3.14 \times 10^{-7} \\
(-0.65)\end{array}$ & $\begin{array}{l}0.012^{*} \\
(4.380)\end{array}$ & 0.42 \\
\hline Yobe & $\begin{array}{l}25.652^{*} \\
(3.098)\end{array}$ & $\begin{array}{l}-1.555^{*} \\
(-2.93)\end{array}$ & $\begin{array}{l}0.000 \\
(-0.913)\end{array}$ & $\begin{array}{l}0.024^{*} \\
(2.876)\end{array}$ & $\begin{array}{l}5.81 \times 10^{-7} \\
(0.539)\end{array}$ & $\begin{array}{l}0.019^{*} \\
(6.959)\end{array}$ & 0.55 \\
\hline Zamfara & $\begin{array}{l}-0.812 \\
(-1.171)\end{array}$ & $\begin{array}{l}0.078^{* *} \\
(1.680)\end{array}$ & $\begin{array}{l}0.000 \\
(-0.241)\end{array}$ & $\begin{array}{l}-0.001^{* *} \\
(-1.784)\end{array}$ & $\begin{array}{l}0.078^{* *} \\
(1.690)\end{array}$ & $\begin{array}{l}0.006^{*} \\
(4.364)\end{array}$ & 0.41 \\
\hline
\end{tabular}




\section{REFERENCES}

1. Anderson RJ Impact of Climate Variability in Australian Agriculture: A Review. Review of Marketing and Agricultural Economics 1979; 47 (3): 147177.

2. Deressa T, Hassan $\mathbf{R}$ and $\mathbf{D}$ Poonyth Measuring The Impact of Climate Change on South African Agriculture: The Case of Sugar Cane Growing Regions. Agrekon 2005; 44 (4): 524-542.

3. Mendelsohn R, Nordhaus WD and D Shaw The impact of global warming on agriculture: A Ricardian analysis. American Economic Review 1994; 84: $753-771$.

4. Torvanger A, Twena $M$ and $B$ Romstad Climate change impacts on agricultural productivity in Norway. CICERO Working Paper 2004; 10.

5. Reinsborough $\mathbf{M}$ A Ricardian model of climate change in Canada. Canadian Journal of Economics 2003; 36: 21-40.

6. Mendelsohn $\mathbf{R}$ and $\mathbf{A}$ Dinar Climate, water, and agriculture. Land Economics 2003; 79 (3): 328-341.

7. Kurukulasuriya $\mathbf{P}$ and MI Ajwad Application of the Ricardian technique to estimate the impact of small holder farming in Sri Lanka. Climate Change 2007; 81: 39-59.

8. Molua EL and CM Lambi The economic impact of climate change on agriculture in Cameroon. The World Bank Policy Research Working Paper 2007; 4364: 1-31.

9. Eid HM, El-Marsafawy SM and SA Oudai Assessing the economic impacts of climate change on agriculture in Egypt: A Ricardian approach. Research Journal of Agriculture and Biological Sciences 2006; 2 (6): 316-322.

10. IPCC. (Intergovernmental Panel on Climate Change). Impacts, adaptations and mitigation of climate change: Scientific-technical analyses. Cambridge University Press, Cambridge, UK. 1996.

11. Adejuwon SA "The impacts of climate variability and climate change on crop yield in Nigeria". Paper presented at stakeholders' workshop on assessment of impacts and adaptation to climate change Obafemi Awolowo University, IleIfe, Nigeria 2004.

12. FAO. Food and Agricultural Organization of the United Nations statistical database 2007. www.fao.org Accessed in 2008. 